\title{
REFORMASI PELAYANAN PUBLIK BIDANG IZIN MENDIRIKAN BANGUNAN DI DAERAH
}

Muhammad Idris

Fakultas Ilmu Sosial dan Ilmu Politik Universitas Muhammadiyah Makassar Jl. Sultan Alauddin No. 259 Makassar 90221 Telp. 0411 - 866972 ext. 102 Fax. 0411 - 865588

\begin{abstract}
In reformation era, as now, the implementation of the development of specific public services in the service of Building Permit (IMB), it is time to use the principles of quality management-oriented activities to improve and enhance public service delivery is increasingly competitive, and in anticipation of increased globalization and the need received international recognition for quality and process of public service. Public service management system is required with respect to the development of globalization so that the demand for minimum service standards can be actualized in order to improve public services. Thus, the behavior of the bureaucracy in the service delivery of licensing services, local authorities have time to do a public service reform minimum quality standards in public service. Reforms intended primarily; institutional model to a one-stop service, publish a minimum service standards, increase surveillance, patterns of human resource development personnel, and public participation.
\end{abstract}

Keywords: Reform, Public Services, Building Permits

\section{ABSTRAK}

Di era reformasi seperti sekarang ini, pelaksanaan pengembangan layanan publik tertentu dalam pelayanan Ijin Mendirikan Bangunan (IMB), sekarang saatnya untuk menggunakan prinsip-prinsip manajemen mutu yang berorientasi kegiatan untuk memperbaiki dan meningkatkan pelayanan publik yang semakin kompetitif, dan untuk mengantisipasi perkembangan globalisasi dan kebutuhan mendapatkan pengakuan internasional untuk kualitas dan proses pelayanan publik. Layanan sistem manajemen publik diperlukan sehubungan dengan perkembangan globalisasi sehingga permintaan untuk standar pelayanan minimum dapat diaktualisasikan dalam rangka meningkatkan pelayanan publik. Dengan demikian, perilaku birokrasi dalam pelayanan jasa perizinan, pemerintah daerah memiliki waktu untuk melakukan standar pelayanan publik minimal reformasi kualitas dalam pelayanan publik. Reformasi dimaksudkan terutama; model kelembagaan ke layanan satu atap, menerbitkan standar pelayanan minimum, peningkatan pengawasan, pola personil pengembangan sumber daya manusia, dan partisipasi masyarakat.

Kata kunci: Reformasi, Pelayanan Publik, Izin Bangunan 


\section{A. LATAR BELAKANG MASALAH}

Pelayanan Publik adalah segala kegiatan dalam rangka pemenuhan kebutuhan dasar sesuai dengan hak-hak dasar setiap warga negara dan penduduk atas suatu barang, jasa dan atau pelayanan administrasi yang disediakan oleh penyelenggara pelayanan yang terkait dengan kepentingan publik. Penyelenggara Pelayanan Publik adalah lembaga dan petugas pelayanan publik baik Pemerintah Daerah maupun Badan Usaha Milik Daerah yang menyelenggarakan pelayanan publik. Adapun Penerima Layanan Publik adalah perseorangan atau kelompok orang dan atau badan hukum yang memiliki hak dan kewajiban terhadap suatu pelayanan publik.

Pelayanan publik menurut Keputusan Menteri Pendayagunaan Aparatur Negara Nomor: Kep/25/M.Pan/2/2004 Tentang Pedoman Umum Penyusunan Indeks Kepuasan Masyarakat Unit Pelayanan Instansi Pemerintah, dinyatakan bahwa Pelayanan publik adalah segala kegiatan pelayanan yang dilaksanakan oleh penyelenggara pelayanan publik sebagai upaya pemenuhan kebutuhan penerima pelayanan, maupun dalam rangka pelaksanaan ketentuan peraturan perundangundangan.

Pelayanan publik oleh aparatur pemerintah dewasa ini masih banyak dijumpai kelemahan sehingga belum dapat memenuhi kualitas yang diharapkan masyarakat. Hal ini ditandai dengan masih adanya berbagai keluhan masyarakat yang disampaikan melalui media massa, sehingga dapat menimbulkan citra yang kurang baik terhadap aparatur pemerintah. Mengingat fungsi utama pemerintah adalah melayani masyarakat maka pemerintah perlu terus berupaya meningkatkan kualitas pelayanan.

Masyarakat yang merupakan pelanggan dari pelayanan publik, juga memiliki kebutuhan dan harapan pada kinerja penyelenggara pelayanan publik yang profesional. Sehingga yang sekarang menjadi tugas Pemerintah Pusat maupun Pemerintah Daerah adalah bagaimana memberikan pelayanan publik yang mampu memuaskan masyarakat. Adanya implementasi kebijakan desentralisasi dan otonomi daerah di Indonesia yang tertuang dalam UU tentang Pemerintahan daerah menyebutkan bahwa Pemerintah mempunyai tanggung jawab, kewenangan dan menentukan standar pelayanan minimal, hal ini mengakibatkan setiap Daerah (Kota/ Kabupaten) di Indonesia harus melakukan pelayanan publik sebaik-baiknya dengan standar minimal.

Keterkaitan dengan pemberian otonomi kepada daerah berdasarkan Undang-undang Nomor 32 Tahun 2004 tentang pemerintahan daerah. Undang-undang ini didasari oleh filosofi keanekaragaman dalam kesatuan dengan pendekatan besaran dan isi otonomi yang menekankan pada pembagian urusan yang berkeseimbangan berdasarkan asas eksternalitas, akuntabilitas dalam memberikan pelayanan kepada masyarakat. Secara umum pemberian otonomi ditujukan adalah untuk:

1. Meningkatkan pelayanan dan kesejahteraan masyarakat yang semakin baik;

2. Mengembengkan kehidupan demokrasi, keadilan, dan pemerataan;

3. Memelihara hubungan yang serasi antara Pusat dan Daerah, serta antardaerah dalam rangka menjaga keutuhan Negara Kesatuan Republik Indonesia.

Dengan demikian, jelaslah bahwa penyelenggaraan pemerintahan daerah dengan otonomi yang luas, nyata, dan bertanggungjawab berdasarkan Undang-undang tersebut salah satunya adalah untuk meningkatkan pelayanan publik, sehingga mampu meningkatkan kesejahteraan masyarakat. Dalam konteks ini, pelayanan publik dan kesejahteraan masyarakat bukan hanya harus meningkatkan dengan adanya keleluasaan otonomi pada daerah, akan tetapi peningkatan pelayanan dan kesejahteraan masyarakat tersebut haruslah menjadi semakin baik. Hal ini berarti, bahwa intensitas pelayanan atau tingkat kesejahteraan masyarakat itu meningkat, seiring dengan terwujudnya kualitan pelayanan yang semakin baik.

Meskipun demikian, dalam kenyataanya pelayanan publik di daerah tidak sesuai dengan harapan karena secara empiris pelayanan publik, khusus pada pelayanan bidang perizinan 
daerah dalam implementasinya masih terkesan berbelit-belit, lambat, mahal, melelahkan, dan bahkan masih dijumpai tidak transparans, serta kurang adil. Kenyataan ini, sering berakibat timbulnya pandangan negatif masyarakat sebagai "custemer" atau pengguna layanan, yang akhirnya merupakan keluhankeluhan terhadap pelayanan. Kecenderungan itu, terjadi sebagai dampak dari perilaku birokrasi yang masih memposisikan masyarakat sebagai pihak yang melayani, dan bukan yang dilayani. Sesungguhnya standar pelayanan minimal ditujukan pelayanan pada masyarakat umum, namun terkadang dibalik menjadi pelayanan masyarakat terhadap negara.

Sebagaimana kebijakan pemerintah yang dituangkan dalam PP Nomor 65 Tahun 2005 tentang Pedoman Penyusunan dan Penerapan Strandar Pelayanan Minimal (SPM). PP ini berisi ketentuan mengenai jenis dan pelayanan dasar yang menjamin akses masyarakat untuk mendapatkan pelayanan dasar dari pemerintah daerah sesuai dengan ukuranukuran yang ditetapkan oleh pemerintah. Selanjutnya Standar Pelayanan Minimal dengan prinsip-prinsipnya, yaitu sederhana, konkret, mudah diukur, terbuka, terjangkau dan dapat dipertanggungjawabkan, serta mempunyai batas waktu pencapaian.

Dengan demikian, pelaksanaan pengembangan pelayanan publik khusus pada pelayanan Izin Mendirikan Bangunan (IMB) , sudah saatnya menggunakan prinsip-prinsip manajemen yang berorientasi pada mutu guna memperbaiki dan menyempurnakan kegiatan penyelenggaraan pelayanan publik yang semakin kompetitif, dan sebagai antisipasi perkembangan globalisasi serta perlunya mendapat pengakuan internasional terhadap mutu dan proses pelayanan publik. Sistem manajemen pelayanan publik diperlukan dengan memperhatikan perkembangan globalisasi sehingga tuntutan akan Standar Pelayanan Minimal dapat diaktualisasikan dalam rangka peningkatan pelayanan publik.

\section{B. PERMASALAHAN}

Dipahami bahwa salah satu bagian dari proses penyelenggaraan pemerintahan di daerah adalah mengharapkan kualitas pelayanan publik yang lebih baik. Pelaksanaan pelayanan IMB di daerah selama ini, dipandang masyarakat belum akuntabilitas, efisien, dan efektif sehingga masyarakat sebagai penerima layanan tidak terpuaskan. Sehubungan dengan hal tersebut, maka ada pertanyaan penting yang perlu dijawab untuk memenuhi tuntutan pelayanan publik di bidang pengurusan IMB di daerah, sebagai berikut:

1. Bagaimana kualitas Pelayanan pengurusan IMB di daerah

2. Faktor-faktor apa yang mempengaruhi peningkan kualitas pelayanan IMB.

3. Bagaimana reformasi pelayan yang dibutuhkan untuk memenuhi Standar Pelayanan Minimal pelayanan IMB

\section{PEMBAHASAN}

\section{Kerangka Konseptual Kualitas Pelayanan Publik}

Berbicara mengenai kualitas pelayanan, Zeithaml, Parasuraman, dan Berry (1990) mengemukakan bahwa dengan pelayanan yang prima (Service Excellence) setiap orang menjadi pemenang; baik para pengguna layanan, para karyawan, manajemen, para pemilik atau stockholders, masyarakat, maupun negara/daerah. Konsep ini menunjukkan bahwa betapa pentingnya arti sebuah kualitas, baik dalam penyelenggaraan usaha produksi barang maupun jasa-jasa, termasuk pelayanan publik yang dilaksanakan oleh aparatur pemerintah baik di Pusat, Provinsi, maupun di kabupaten/kota, Kecamatan dan bahkan di Kelurahan/desa. Dengan demikian, pengertian prima dalam hubungannya dengan kualitas pelayanan ataupun kualitas produk bukan hanya diucapkan, tetapi memberikan pelayanan sesuai yang dijanjikan, sehingga masyarakat tidak mengeluh, kecewa, dan tidak memandang pemberian layanan yang buruk.

Salah satu penyebab terjadinya krisis kepercayaan masyarakat kepada birokrasi pemerintahan, bahkan terhadap aparat keamanan dan penegak hukum, pada dasarnya dipicu oleh kegagalan aparatur birokrasi 
dalam menampilkan kualitas layanan prima kepada masyarakat sesuai bidang masingmasing. Akibatnya citra birokrasi pemerintahan menjadi sangat buruk di mata sebagian masyarakat. Dengan demikian, prestasi dan kinerja para birokrat dan aparat dalam menjalankan tugasnya dinilai buruk manakala kepentingan masyarakat sebagai pengguna jasa terabaikan. Sebaliknya, manakala masyarakat sebagai pengguna atau pemanfaat jasa pelayanan tertentu tidak mengeluh dan menunjukkan kepuasan atas layanan yang diterimanya, maka dapat dinilai berkualitas.

Menentukan penilaian terhadap kualitas pelayanan memang bukan pekerjaan mudah, karena karakteristik nilai bagi semua orang tentunya berbeda satu sama lain berdasarkan presfektif masing-masing. Namun demikian, bukan berarti tidak dapat diukur dan dijelaskan aspek-aspek yang merupakan indikator dengan berbagai pendekatan teori untuk mendeskripsikannya. Seperti, misalnya dikemukakan oleh Parasurahman, (Jurnal JIANA, 2010) bahwa terdapat lima dimensi yang digunakan oleh pelanggan untuk menentukan kualitas pelayanan, yakni : (1) bukti langsung (tangibles), (2) keandalan (reliability), (3) daya tanggap (responsiveness), (4) jaminan (assurance), dan empati (empaty).

Lebih lanjut dijelaskan, bahwa pendapat tersebut pada awalnya dikaitkan dengan pelayanan yang diberikan dalam sektor privat. Pada perkembangan lebih lanjut justru banyak digunakan untuk menggambarkan kualitas pelayanan di sektor publik. Hal ini oleh para pendukung pendapat ini berasumsi bahwa kualitas pelayanan pada sektor publik dan sektor privat adalah sama walupun masingmasing memiliki batas-batas tertentu. Salah satu pendapat dari Rainey, (Jurnal JIANA, 2010) membuat ringkasan pendapat mengenai kekhasana karakter dari organisasi dan manajemen publik dengan menyatakan bahwa kekhasan karakter tersebut dapat dikelompokkan ke dalam : faktor lingkungan, transaksi organisasi lingkungan, peranan dan struktur, dan proses keorganisasian. Dengan demikian, kualitan pelayanan pada sektor publik sangat ditentukan oleh lingkungan organisasi, baik internal maupun lingkungan ekternal.
Pandangan-pandangan tersebut semakin memperjelas konsep kualitas pelayanan publik yang diarahkan pada peranan perilaku individu dan biroksi, khususnya pada pelayanan pemerintahan. Ndraha, (2005) memberikan pernyataan singkat mengenai kualitas pelayanan publik adalah dapat diamati dari empat dimensi, yakni : Pengertian (understanding), penerimaan (legitimation), kepercayaan (trust), dan keterbukaan (openess). Pandangan ini sebenarnya tidak jauh berbeda dengan Rainey, tetapi saling melengkapi dalam memahami konsep pelayanan, baik yang dilayani maupun yang melayani.

Dengan demikian, jika dianalisis lebih mendalam, maka sesungguhnya kualitas pelayanan sedikitnya harus termuat dimensidimensi: penerimaan, kepercayaan, keterbukaan, keadilan, responsif, dan akuntabilitas. Hal ini, berarti kualitas pelayanan sangat ditentukan oleh perilaku baik yang dilayani, dan terutama yang melayani yang tercermin dalam perilaku birokrasi. Sehingga salah satu upaya dalam pemberdayaan individu tidak terlepas dari motivasi kerja yang diarahkan sesuai tingkatan dan kebutuhannya. Berikut ini akan dijelaskan dalam pokok pembahasan makalah ini.

\section{Komponen Kualitas Pelayanan Publik}

Kualitas pelayanan yang diharapkan oleh masyarakat, maupun kualitas pelayanan yang dipersepsikan oleh lembaga pemberi pelayanan kepada masyarakat; berdasarkan pengalaman dan penelitian yang dilakukan oleh Zeithaml dkk, (Jurnal Administrasi Publik, 2003), mengatakan terdapat beberapa komponen atau variable kualitas pelayanan kepada masyarakat. Komponen-komponen pelayan prima tersebut adalah terdiri dari beberapa dimensi, sebagai berikut:

1. Wujud; yaitu penampilan fisik fasilitas lembaga pelayanan, peralatan yang digunakan, pegawai atau petugas pelayanan, dan peralatan bantu komunikasi.

2. Kemampuan Terpercaya; yaitu kemampuan untuk menampilkan kinerja pelayanan yang dijanjikan secara tepat dan akurat. 
3. Daya Tanggap; yaitu kemauan untuk membantu dan melayani masyarakat konsumen secara segera sesuai dengan permintaan ataupun harapan masyarakat.

4. Kompetensi; yaitu penguasaan atas pengetahuan dan keterampilan yang diperlukan untuk memberikan pelayanan tertentu.

5. Kesantunan; yaitu sikap yang ditunjukkan pada saat memberikan pelayanan yang umumnya terdiri dari kesopanan, penghargaan terhadap masyarakat, perhatian, pertimbangan, kebijaksanaan, dan sikap bersahabat.

6. Kredibilitas; yaitu tingkat kepercayaan atau jaminan mutu, kesungguhan, kejujuran yang ditunjukkan oleh petugas atau lembaga pelayanan kepada masyarakat.

7. Keamanan; yaitu berkaitan dengan seberapa jauh pelayanan jasa yang diberikan bebas dari kesalahan dan resiko yang akan ditanggung masyarakat, memberikan rasa aman, dan bebas dari keraguan.

8. Akses; yaitu kemudahan untuk menemukan lokasi pelayanan atau kemudahan untuk menemui petugas layanan.

9. Komunikasi; yaitu bagaimana lembaga pelayanan memelihara hubungan dengan masyarakat konsumennya dengan cara regular mengirimkan informasi dengan berbagai cara.

10.Memahami Kehendak Masyarakat; yaitu kemampuan lembaga dan para petugas layanan memiliki kemampuan dan berusaha sebaik mungkin untuk memahami berbagai kehendak, kebutuhan, maupun keinginan masyarakat yang beragam, dan menyesuaikan dengan tingkat pelayanan yang diberikan.

\section{Model Kesenjangan Kualitan Pelayanan Publik}

Memahami langkah-langkah kebijakan yang ditempuh dalam upaya meningkatkan kualitas pelayanan public, khusus oleh pemerintah daerah, sebaiknya dipahami pula model analisis bagaimana mengidentifikasi permasalah dalam rangka pemberian pelayanan kepada masyarakat. Salah satu model yang dapat digunakan adalah Model Kesenjangan Pelayanan yang dikembangkan oleh Zeithaml, Parasuraman, dan Berry (1990), sebagai kerangka analisis untuk mengevakuasi permasalahan yang berkaitan dengan kualitas pelayanan, berdasarkan kesenjangankesenjangan yang terjadi antara apa yang diharapkan oleh masyarakat konsumen dan apa yang dirumuskan dan ditetapkan oleh lembaga dan petugas pemberi pelayanan.

Zeithaml, menjelaskan bahwa terdapat 4 kesenjangan (gap) yang secara berjenjang menjelaskan tentang bagaimana mengukur kualitas pelayanan publik, sebagai berikut:

Gap1: menjelaskan bahwa rendahnya kualitas pelayanan publik karena karena adanya kesenjangan antara apa yang sesungguhnya diharapkan oleh masyarakat dengan yang dipersepsikan oleh penyedia layanan.

Gap 2: menjelaskan bahwa sesungguhnya penyedia layanan mengetahui apa yang diharapkan oleh masyarakat, namun dalam prakteknya, layanan yang diberikan tidak sama dengan yang diharapkan oleh masyarakat.

Gap 3: menjelaskan bahwa apa yang diharapkan oleh masyarakat sudah dipahami dan dibuatkan standar pelayanan oleh pemberi layanan sebagaimana harapan masyarakat, namun demikian layanan yang diberikan tidak sebagaimana standar yang sudah ditentukan sebelumnya.

Gap 4: menjelaskan bahwa sudah ada konsistensi antara harapan masyarakat, persepsi pemberi layanan dan sudah dibuatkan standar pelayanan sebagaimana yang diharapkan dan dipesepsikan oleh pemberi layanan, namun dalam pelaksanaannya tidak berjalan sebagaimana dengan yang diinformasikan kepada masyarakat.

\section{Pembahasan Kualitas Pelayanan Izin Mendirikan Bangunan (IMB)}

Zeithaml, dkk (1990) mengemukakan bahwa penyebab utama persepsi kualitas pelayanan rendah adalah kesenjangan antara apa yang dijanjikan perusahaan tentang layanannya dan apa yang sesungguhnya diberikan. Ketepanan dan keakuratan apa yang dikomunikasikan tentang layanan yang 
diberikan sangat tergantung pada bagian pemasaran dan bagian operasional. Oleh karena apa yang dikomunikasikan oleh bagian pemasaran tentang kualitas layanan yang menjadi tanggungjawabnya haruslah sesuai dengan apa yang dikerjakan oleh bagian operasional. Jika apa yang disampaikan atau dikomunikasikan bagian pemasaran tidak sesuai dengan apa yang diharapkan pelanggan, akan berakibat pada kekecewaan pelanggan tentang kualitas pelayanan yang diberikan.

Salah satu bentuk pelayan IMB adalah adanya kesenjangan Another form of coordination central to providing service quality is consistency in policies and procedures across departments and koordinasi antara kebijakan dan prosedur seluruh departemen dan cabang. If a service organization operates many outlets under the same name, whether franchised or company-owned, customers expect similar performance across those outlets. Jika organisasi jasa beroperasi dengan banyak outlet dan dengan nama sama, apakah waralaba atau perusahaan yang dimiliki, pelanggan mengharapkan kinerja yang serupa di outlet.

If managers of individual branches or outlets have significant utonomy in procedures and policies, customers may not receive the same level of service quality across the branches. Jika manajer cabang atau outlet memiliki otonomi yang signifikan dalam prosedur dan kebijakan, pelanggan cenderung tidak dapat menerima kualitas pelayanan pada tingkat yang sama di cabang. In this case, what they expect and receive from one branch may be different from what is delivered in other branches. Under these circumstances, the size of Gap 4 can be large. Dalam hal ini, apa yang mereka harapkan dan yang mereka terima dari satu cabang mungkin berbeda dari apa yang disampaikan di cabang lain.

A question frequently asked by companies is, "How much standardization can we achieve across branches without taking away the autonomy and perceived control of managers?" Sebuah pertanyaan yang sering diajukan oleh perusahaan adalah, "Berapa banyak standardisasi yang dapat kita terapkan pada seluruh cabang, tanpa menguangi otonomi dan kontrol terhadap seluruh cabang tersebut".
Yang menjadi masalah adalah bagaimana menjamin bahwa standar pelayanan yang ditetapkan disebuah outlet tidak menganggu persepsi dan harapan pelanggan pada pelayanan outlet lainnya, jika saja para manajer outlet diberi kewenangan untuk melayani pelanggan dengan cara mereka sendiri. At issue is the need to assure con sistency across outlets (so that expectations set by one outlet do not interfere with perceptions of service at another outlet) while allowing the managers autonomy to serve customers in their own ways. Salah satu contoh maklumat pelayanan izin IMB Kota Makassar, yakni :

Kepala Dinas Tata Ruang Bangunan Kota Makassar, Andi Oddang Wawo menegaskan, sebagai wujud peningkatan pelayanan prima ke masyarakat, pengurusan izin mendirkan bangunan yang tadinya dua belas hari kerja, dipangkas menjadi enam hari kerja. Pemangkasan ini, guna memudahkan masyarakat memperoleh IMB. Dinas tata ruang bangunan kota Makassar memberikan kemudahan bagi masyarakat yang hendak memiliki izin mendirikan bangunan, tidak perlu lagi menunggu hingga dua belas hari kerja, melainkan cukup enam hari kerja sesuai prosedur dan mekanisme yang berlaku. Pemangkasan sistem birokrasi pengurusan IMB di dinas tata ruang bangunan tak terlepas dari komitmen pemerintah dalam memberikan pelayanan prima ke masyarakat khususnya bagi pemohon IMB di Makassar.

Disisi lain, dinas tata ruang bangunan berharap, untuk tercapainya peningkatan PAD kedepan, dipandang perlunya optimalisasi kegiatan pelayanan serta pembinaan masyarakat, sehingga DTRB saat ini mengharapkan adanya penambahan personil yang profesional yang menguasai teknis pada dinas tata ruang bangunan.

(Sumber:http://makassartv.co.id/index.php? option $=$ com_content\&view $=$ article \&id=828: dtrb-pangkas-birokrasi-pengurusanimb\&catid=3:berita-umum\&Itemid=56, akses 20 Oktober 2010).

Informasi ini menunjukkan betapa mudahnya menggambarkan tentang janji birokrasi terhadap pelayanan publik yang menjadi tanggung jawab mereka. Kantor Pelayanan 
Administrasi Perizinan (KPAP) dan Dinas Tata Ruang dan Bangunan (DTRB) berusaha membangun citra kepada publik tentang kualitas layanan mereka, bahkan diwaktu lain, mereka justru mengumbar bahwa mereka dapat menyelesaikannya dalam waktu 6 hari kerja.

Namun pada kenyataannya tanggapan pelanggan terhadap pelayanan IMB berikut sangat berbeda dengan apa yang dijanjikan Birokrasi perizinan terhadap pelanggan. Bahkan menggambarkan keluhan seorang pelanggan yang mengurus IMB dan berusaha untuk memperoleh simpati publik dengan mengadu halnya kepada DPRD Kota Makassar untuk mendapatkan tanggapan.

Dengan demikian, kenyataan di atas menunjukkan tentang ketidakkonsistenan antara apa yang dikomunikasikan kepada masyarakat sebagai penerima layanan dengan apa yang dialami oleh masyarakat. Ketidakkonsistenan antara apa yang dijanjikan pemberi layanan dengan yang diberikan kepada masyarakat dalam pelayanan publik Izin Mendirikan Bangunan (IMB) di Kota Makassar.

Salah satu faktor yang menyebabkan kondisi ini terjadi karena komunikasi yang terjalin antara bagian-bagian dalam unit kerja tidak singkron antara yang satu dengan yang lainnya. Pengurusan IMB sesungguhnya berada pada 2 kamar yang berbeda, yaitu: (1) Kantor Pelayanan Administrasi Perizinan (KPAP) Kota Makassar sebagai pelaksana kegiatan peng-administrasian seluruh jenis perizinan di Kota Makassar; dan (2) Dinas Tata Ruang dan Bangunan (DTRB) Kota Makassar sebagai pelaksana teknis pengurusan IMB.

Selain itu, hasil temuan Saifullah K. (2010) "Tentang Pelayanan IMB pada Kantor Pelayanan Terpadu Kabupaten Gowa" bahwa :

1. Standar pelayanan minimum penyelesaian permohonan izin mendirikan bangunan (IMB) selama 12 hari kerja, belum dilaksakan secara konsisten. Permohonan tersebut sering berkasnya tidak diteruskan ke Kantor Pelayanan Perizinan, sehingga memakan waktu yang cukup lama karena harus memenuni syarat administrasi dimaksud.

2. Sering juga pemohon tidak melalui prosedur berlaku alias menggunakan jasa calo sehingga tidak dapat dibuktikan bahwa proses itu berjalan sesuai ketentuan. Dengan kata lain, jangan sampai perantara tersebut tidak menyalurkan permohonan Anda dengan cara sengaja mengulur-ulur waktu sehingga proses pengurusan IMB jadi lama dan tidak jelas penyelesaiannya.

Dengan demikian, pelaksanaan pelayan perizinan di daerah merupakan salah satu permasalah yang tidak pernah terselesaikan dengan baik. Masalahnya adalah perilaku birokrasi yang terkait dengan pemberian pelayanan perizinan masih dipandang "diskriminatif" kalangan masyarakat sebagai orang yang terlayani.

\section{SOLUSI PENINGKATAN KUALITS PELAYANAN IMB DI DAERAH}

Berdasarkan dengan kenyataan perilaku birokrasi dalam pemberian pelayanan pelayanan perizinan, pemerintah daerah sudah saatnya melakukan Reformasi Pelayanan Publik yang berkualitas sesuai standar minimal dalam pelayanan publik. Berikut ini, dikemukakan beberapa solusi meningkatkan kualitas pelayanan publik sebagai berikut :

1. Bahwa untuk merubah sikap/budaya organisasi, ada beberapa alternatif meningkatkan kualitas pelayanan: (a) melakukan reformasi internal dari aparat birokrasi tentang tugas atau jabatan yang diembangnya. Karena persepsi selama ini bahwa aparat dibutuhkan masyarakat harus berubah bahwa aparatlah yang membutuhkan masyarakat. (2) Peningkatan suasana kompetisi yang sehat dalam memberikan pelayanan. Bagi mereka yang berprestasi perlu diberikan reward, bagi mereka yang tidak berprestasi perlu di berikan punishment yang bersifat mendidik. (3) Mendeskripsikan dan mempublikasikan stantar pelayanan yang baik yang menyangkut kualitas, besarnya biaya, waktu sesuai dengan jenis pelayanan yang diberikan. (4) Peningkatan moralitas aparat terutama yang berkaitan dengan hak, kewajiban dan tanggungjawab baik secara sosial, administratif, 
maupun spritual. (5) Secara eksternal, perlu adanya peningkatan sense of responsibility dari masyarakat yang menyangkut upaya penyadaran terhadap hak-hak sebagai warga negara dalam memperoleh pelayanan yang terbaik. Menyampaikan keluhan atau penyimpangan.

2. Menciptakan lingkungan organisasi yang transparan yang memaksa aparat berperilaku sesesuai prosedur. Alasannya karena lingkungan dinas perizinan yang kurang transparan dan tidak adanya kontrol eksternal, ditambah banyaknya instansi yang terlibat dalam penyelesaian urusan perizinan, telah menciptakan ruang yang nyaman dan aman tumbuhnya motif-motif yang kuat yang berorientasi pada kepentingan pribadi aparat.

3. Model dalam meningkatkan kualitas pelayanan publik antara lain; (1) Model Kelembagaan, yaitu format kelembagaan One Stop service (OSS) difungsikan sebagai frontline dari dinas-dinas yang ada untuk menjadi satu-satunya lembaga yang berhubungan dengan masyarakat yang memerlukan berbagai pelayanan. (2) Model Pengelolaan Organisasi Pelayanan Publik, yaitu memberdayakan lembaga pelayanan publik sehingga dapat mengoptimalkan fungsi pelayanan publik sesuai dengan perkembangan tuntutan perkembangaan ekonomi, politik, sosial, dan budaya. (3) Model Siklus Layanan, yaitu tetap melaksanakaan kewenangan dan tugas-fungsinya yang diatur sesuai prosedur. Tetapi teknis pelaksanaan dengan pola pelayanan umum satu atap. (3) Model Standar Pelayanan Minimal, yaitu menggali pandangan masyarakat terhadap mutu pelayanan yang diberikan oleh OSS yang didasarkan pada indikator standar pelayanan.

4. Dalam upaya meningkatkan pelayanan perizinan Mendirikan Bangunan (IMB), langkah yang dapat ditempuh yaitu; (1) Peningkatan pengawasan sebagai instrumen kendali disiplin Aparat Pelayanan
Permohonan IMB, (2) Penerapan pola pembinaan yang tepat dan berdaya guna dengan pendisiplinan yang manusiawi dalam meningkatkan kualitas pelayanan permohonan IMB kepada Masyarakat, (3) Keteladanan Pimpinan dalam menyegerakan melayani pemohon IMB.

\section{E KESIMPULAN}

Berdasarkan uraian sebelumnya, reformasi pelayanan publik bidang IMB di daerah, maka dapat dikemukakan beberapa simpulan:

1. Standar kualitas pelayanan IMB di daerah masih menunjukkan stantar pelayanan kurang maksimal, karena masih terdapat kesenjangan antara janji Birokrasi dengan pelayanan yang dirasakan oleh masyarakat sebagai pelanggan. Konsistensi terhadap penyelesaian IMB masih lamban dan sering mensyatkan yang mempersulit pemohon.

2. Ada beberapa faktor yang sering bersentuhan langsung dengan kualitas pelayanan IMB: masih adanya kewenang lebih dari satu departeman dan tidak jelas garis koordinasinya, sikap/budaya birokrasi pelayanan masih rendah, dan sikap masyarakat pemohon masih tidak menyadari memenuhi prosedur yang resmi sehingga mempersulit aparat melakukan kualitas yang terbaik dan adil.

3. Solusinya meningkatkan kualitas pelayanan adalah: Reformasi model kelembagaan ke pelayanan satu atap, publikasikan standar pelayanan minimal, tingkatkan pengawasan, pola pembinaan SDM aparatur, dan tumbuhkan partisipasi masyarakat tentang pentingnya prosedur pelayanan.

\section{DAFTAR PUSTAKA}

Dwiyanto, Agus. Dkk. 2005. "Pengamatan untuk Menilai Kinerja Pelayanan Publik", dalam Mewujudkan Good Governance Melalui Pelayanan Publik. Yogyakarta: UGM Press. 

Gedeona, Hendrikus Tri Wibawanto, 2010, "Pendekatan Kualitatif Dan Kontribusinya Dalam Penelitian Administrasi Publik" Jurnal Jurnal Ilmu Administrasi, Vol.VII (3), September 2010, (hal. 183192)

Gibson, dkk. (1996). Organisasi: Perilaku, Struktur dan Proses, Binarupa Aksara, Jakarta.

Goodsell, C.T. 2006. "A New Vision Public Administration", dalam Public Administration Review, (Jul/Agust, 06), 4, Academic Research Library, (pp. 623-635)

Ndraha, Talizidulu, (2005). Kybernology : Sebuah Konstruksi Ilmu Pemerintahan, Jakarta : Rineka Cipta.

Robbins, Stephen P., (2003). Perilaku Organisasi, (Jilid 2), Terjemahan, Jakarta : PT. Indeks Kelompok Gramedia,

Rondinelli, D.A. 2007. “Government Serving People: The Changing Role of Public Administration in Democratic Governance", dalam Public Administration and Democratic Governance: Governments
Serving Citizens. New York: United Nations: Economic and Social Affairs.

Saifullah K. (2010). Pelayanan Pengurusan Izin Mendirikan Bangunan (IMB) di Kantor Pelayan terpadu Kabupaten Gowa (Tesis), Universitas Muhammadiyah Makassar, Makassar.

Suryani, Ade Irma, (2008). Implementasi Penerbitan Ijin Mendirikan Bangunan (IMB) Dalam Perspektif Azas-Azas Umum Pemerintahan Yang Baik Di Kabupaten Sukamara, Universitas Diponegoro, Semarang.

Tobirin, 2008, "Penerapan Etika Moralitas Dan Budaya Malu Dalam Mewujudkan Kinerja PNS Yang Profesional" Civil Service : Jurnal Kebijakan \& Manajemen PNS, Vol.II No. 2 (2008) (Hal. 53-79)

Undang-Undang No. 25 Tahun 2009 Tentang Pelayanan Publik

Zeithaml, Valarie. Parasuraman, dan Leonard L. Berry, (1990). Delivering Quality Service: Balancing Customer Perceptions and Expectations, The Free Press, New York. 